\title{
HOST RANGE AND DISTRIBUTION OF THE PHYTOPLASMA CAUSING ARIZONA ASH DECLINE
}

\author{
By Jerald S. Bricker ${ }^{1}$ and Jean C. Stutz ${ }^{2}$
}

\begin{abstract}
Ash decline (AD), caused by a phytoplasma, is a progressive dieback disease previously reported in Fraxinus velutina. The host range and distribution of $\mathrm{AD}$ is discussed based on samples collected from ash trees sampled from across the state of Arizona, U.S., including both wild-type F. velutina in riparian areas and F. velutina cv. Modesto, F. velutina cv. Rio Grande, and F. uhdei in landscaped areas. The results of the statewide survey indicate that $\mathrm{AD}$ is found in native and cultivated ash trees, with $F$. velutina cv. Modesto exhibiting the highest (100\%) level of disease in the Phoenix metropolitan area. Wild-type F. velutina and F. velutina cv. Rio Grande also exhibited AD symptoms but with lower frequency and severity. Fraxinus uhdei did not exhibit symptoms of AD. Phytoplasma infection was detected in all tree types of $F$. velutina trees using DAPI staining and polymerase chain reaction (PCR) but was not detected in F. uhdei. Higher frequency of phytoplasma infection was detected in tree canopies versus roots in contrast to previous results reported in white ash. PCR was found to be more efficient at detecting the low-titer infection levels typical
\end{abstract} of $F$. velutina in comparison to DAPI staining.

Key Words. Ash yellows; Fraxinus; Fraxinus velutina; Fraxinus uhdei; host specificity; shamal ash; velvet ash.

Ash decline (AD) is a progressive dieback of stems and branches along with a necrosis of leaf tissue in Fraxinus velutina 'Modesto' (see Bricker and Stutz 1992, 2004 for a full description of AD symptoms). The causal agent of the condition has been determined to be a phytoplasma (Bricker and Stutz 2004).

A number of ash species, including Fraxinus velutina Torrey, are native to Arizona, U.S., and at least two additional species, F. uhdei (Wenz.) Lingelsh. (shamal ash) and F. greggii A. Gray (littleleaf ash), are cultivated as landscape trees in the Phoenix and Tucson, Arizona, metropolitan areas. Our initial observations of AD indicated that not all of the ash species and cultivars growing in the Tempe, Arizona, area displayed symptoms of AD.

The purpose of this study was to (1) establish the host range for $\mathrm{AD}$, (2) determine the most effective sampling strategy for detecting phytoplasmas associated with $\mathrm{AD}$, and (3) compare the effectiveness of detecting phytoplasmas using polymerase chain reaction (PCR) techniques versus the DAPI staining test.

In order to address the species and cultivar susceptibility to $\mathrm{AD}$, native and cultivated populations of ash species were surveyed for symptoms of AD and screened for the presence of phytoplasmas to establish the geographic distribution of AD within Arizona.

\section{MATERIALS AND METHODS Phytoplasma Host Range in Arizona} Sample collection. During September 1992, visual surveys were made for symptoms of AD of 57 Fraxinus velutina trees at 11 sites throughout its natural range in Arizona. In October 1992, 108 cultivated F. velutina cv. 'Modesto' trees in Tempe were examined for symptoms of AD and in November 1992 , 50 trees each of F. uhdei and F. velutina cv. 'Rio Grande' were surveyed in the Tempe area (in areas where F velutina cv. 'Modesto' was seen with AD) for symptoms of AD. In September 1992, 26 F. velutina 'Modesto' trees were surveyed in the Tucson, Wickenburg, Miami-Globe, Safford, and Yarnell areas for symptoms of AD. Each tree included within the survey was rated for decline symptoms using the classification system of Silverborg and Ross (1968): class 1 = apparently healthy trees, class $2=$ trees with a few dead branches, class $3=$ trees with foliar symptoms but with less than one-half of the foliar crown dead, class 4 = trees with foliar symptoms and more than onehalf of the foliar crown dead, and class $5=$ dead trees. Additionally, tissue samples were taken from each tree in the survey group and subjected to the DAPI and PCR tests.

\section{PCR Protocol}

Sample collection. Ash stem samples, with leaves attached, were collected from across Arizona and subjected to PCR analysis using methods described in Bricker and Stutz (2004). Nine trees of wild-type Fraxinus velutina, ten of $F$. velutina cv. 'Modesto' from outside the Phoenix metropolitan area, ten of F. velutina cv. 'Rio Grande', and ten of $F$. uhdei were screened using PCR. The test results from the above types of ash were then compared with those obtained for the 51 F. velutina cv. 'Modesto' from the Phoenix area previously published by Bricker and Stutz (2004).

\section{Comparison of DAPI and PCR Tests}

Stems, with the leaves attached, were collected on 14 September and 18 October 1990, as well as on 13 September 1991. For each tree, samples were collected from as many of the following types of branches that were present on the tree at the sampling time: (1) branches with healthy leaves, (2) branches with leaves 
having chlorotic symptoms, (3) branches with leaves having leaf tip and edge necrosis, (4) branches with leaves with "olive" dieback, and (5) branches with witches' brooms. Root cuttings were collected on 13 September 1991. Duplicates were made of each sample for DAPI and PCR testing. The results of the DAPI tests and the PCR DNA amplification procedure were then compared in order to determine how suitable each was for routine phytoplasma detection. Stem samples were processed for both PCR and DAPI testing using the methods outlined in Bricker and Stutz (2004). Root samples were processed by removing dirt and debris from the tissue under running water, and removing the bark tissue for DNA extraction.

\section{RESULTS}

\section{Phytoplasma Host Range in Arizona}

Symptoms of AD were found to occur throughout the state of Arizona. These symptoms included leaf tip or edge necrosis, chlorosis, and witches' brooms. The survey of all the species and cultivars of ash trees in Arizona revealed that only the Modesto ash suffers from the advanced stages of AD (Table 1). Symptoms of $A D$ in Modesto ash were observed in the Phoenix, Tucson, Wickenburg, and Miami-Globe areas, with the highest incidence of disease symptoms occurring in the Phoenix metropolitan area. AD symptoms were also observed in other ash cultivars and species but at a much lower frequency. Wild-type F. velutina ash trees were the only other ash trees, other than the Modesto ash, included within the statewide survey in which any individuals exhibited adwith dieback). Advanced AD symptoms were observed in one population of wild-type F. velutina trees growing along the Verde River in Clarksdale. Overall, however, the statewide status of wild-type F. velutina was apparently healthy (Mean severity rating $[\mathrm{MSR}]=1.21$ ).

Only a few (6\%) of the Rio Grande ash trees surveyed in the Tempe area had symptoms of AD corresponding to class 2 (a few dead branches on the tree), indicating that the cultivar may be susceptible to AD. None of the evergreen ash vanced stages of $\mathrm{AD}$ (with greater than $50 \%$ of the canopy

(F. uhdei) trees included within the AD survey exhibited symptoms of AD.

\section{Comparison of DAPI and PCR Tests}

Using the DAPI staining technique, phytoplasmas were detected in all of the ash species and cultivars tested (Table 2). Positive DAPI tests were obtained from native Fraxinus velutina at seven of the eleven collection sites located across the range of the species in Arizona. Some plants did exhibit symptoms that might be due to $\mathrm{AD}$, and, in $28.3 \%$ of these cases, a positive DAPI test was obtained (Table 2). A number of other individuals appeared completely healthy, but a positive DAPI test was obtained in $18.2 \%$ of those trees tested, thus indicating the presence of an phytoplasma infection. The overall rate of phytoplasma infection, as indicated by positive DAPI tests, in all samples of the native F. velutina, was $27.1 \%$ (Table 1 ).

Phytoplasmas were detected using DAPI in 66.7\% (Table 2) of the samples collected from symptomatic Fraxinus velutina cv. 'Modesto' in Arizona outside the Phoenix metropolitan area. For Modesto ash trees that were apparently healthy, a positive DAPI test was obtained in $27.3 \%$ of the trees tested. Modesto ash trees cultivated outside of the Phoenix metropolitan area yielded an overall 50\% rate of infection as indicated the DAPI test (Table 1). The level of phytoplasma infection in the Modesto ash was found to be highest in the Phoenix metropolitan area, with $75.6 \%$ of the symptomatic trees and $68.7 \%$ of the asymptomatic trees testing DAPI positive (Table 2). The overall rate of phytoplasma infection in Modesto ash trees sampled and tested using DAPI in the Phoenix area was $76.9 \%$ (Table 1). A positive DAPI test was obtained in $38.9 \%$ of the F. uhdei trees and in $33.3 \%$ of the F. velutina cv. 'Rio Grande' samples tested (Table 1).

The DAPI staining method was performed on the 42 ash samples tested using PCR amplification. In $61.9 \%$ of these samples, similar (either both positive or both negative) DAPI staining and PCR results were obtained. The DAPI and PCR tests were not the same in $38.1 \%$ of the samples tested. For $19 \%$ (8 of 42) of the total samples, a positive DAPI test was

Table 1. Mean severity ratings and DAPI test results for various ash trees growing in cultivation and the wild in Arizona that were surveyed for ash decline in fall 1992.

\begin{tabular}{|c|c|c|c|c|}
\hline Species/cultivar & $\begin{array}{l}\text { No. of trees } \\
\text { surveyed }\end{array}$ & $\begin{array}{l}\text { Percentage with } \\
\text { symptoms }\end{array}$ & $\begin{array}{l}\text { Mean } \\
\text { severity } \\
\text { rating* }\end{array}$ & $\begin{array}{l}\text { Percentage } \\
\text { DAPI positive }\end{array}$ \\
\hline Fraxinus velutina, wild type & 57 & 19.3 & 1.21 & 27.1 \\
\hline $\begin{array}{l}\text { F. velutina 'Modesto' cultivated } \\
\text { in Tempe }\end{array}$ & 108 & 100.0 & 4.10 & 76.9 \\
\hline $\begin{array}{l}\text { F. velutina 'Modesto' cultivated } \\
\text { outside Phoenix metropolitan area }\end{array}$ & 26 & 57.7 & 2.27 & 50.0 \\
\hline $\begin{array}{l}\text { F. velutina 'Rio Grande' cultivated } \\
\text { in Tempe }\end{array}$ & 50 & 6.0 & 1.06 & 33.3 \\
\hline F. uhdei cultivated in Tempe & 50 & 0.0 & 1.0 & 38.9 \\
\hline
\end{tabular}

* Mean severity rating $=\Sigma$ class ratings $\div$ number of individuals rated. obtained, while the PCR yielded no product. In $19 \%$ (8 of 42) of the samples, the DAPI test was negative, while a 560 bp fragment was obtained using PCR.

Amplified PCR products were obtained from six of the eight apparently healthy trees included in the study. Phytoplasmas had previously been detected in samples from one of the two negative PCR trees by repeated testing 
Table 2. DAPI test results in healthy and ash-decline symptomatic trees tested in Arizona for the presence of phytoplasma infection.

\begin{tabular}{lll}
\hline & Trees & Percentage \\
Species/cultivar & symptomatic? & DAPI positive \\
\hline Fraxinus velutina, wild type & Yes & 28.3 \\
& No & 18.2 \\
F. velutina 'Modesto' cultivated & Yes & 75.6 \\
in Tempe & No & 68.7 \\
F. velutina 'Modesto' cultivated & Yes & 66.7 \\
outside Phoenix metropolitan area & No & 27.3 \\
F. velutina 'Rio Grande' cultivated & Yes & 33.3 \\
in Tempe & No & 33.3 \\
F. uhdei cultivated in Tempe & No & 38.9 \\
\hline
\end{tabular}

using the DAPI test. No evidence for phytoplasma infection by the DAPI test had been obtained for the other tree, indicating that it was free from phytoplasma infection.

Phytoplasma DNA, using the polymerase chain reaction, was amplified from DNA extracted from leaf samples of native Fraxinus velutina, F. velutina cv. 'Modesto', and F. velutina cv. 'Rio Grande'. A 560 base (Figure 1) pair fragment corresponding to that obtained by Ahrens and Seemüller (1992) was obtained in three of the nine native Arizona ash as well as in three of the ten Modesto ash from outside the Phoenix metropolitan area, 31 of the 51 Modesto ash from within the Phoenix metropolitan area, and in four of the ten Rio Grande ash. Attempts to amplify phytoplasma DNA in the evergreen ash (F. uhdei) failed to yield a product.

Restriction fragment length polymorphism analysis using AluI produced a consistent restriction pattern containing two bands: $296 \mathrm{bp}$ and $191 \mathrm{bp}$. This indicates that the phytoplasmas detected in various ash species in Arizona are most likely of the same type. The relationship of this phytoplasma to other phytoplasmas in the AshY group causing ash yellows is currently unclear (see Bricker and Stutz 2004 for further discussion).

\section{DISCUSSION}

\section{Phytoplasma Host Range in Arizona}

The results of this study indicate that the symptoms of $\mathrm{AD}$ occur throughout Arizona in both native and cultivated ash trees. Phytoplasmas were also detected in ash trees throughout Arizona. Prior to our studies, the closest report of phytoplasma-infected ash trees was by Sinclair et al. (1990) for Fraxinus velutina cv. 'Modesto' ash trees in the Las Vegas, Nevada, area and for native F. velutina in Zion National Park, Utah.

Although there were some symptoms of $\mathrm{AD}$, and the presence of phytoplasmas was detected in all of the various types of ash trees, there is a difference in the extent of $\mathrm{AD}$ symptoms among the ash cultivars and species. Modesto ash trees were the most severely affected by $\mathrm{AD}$, especially in the

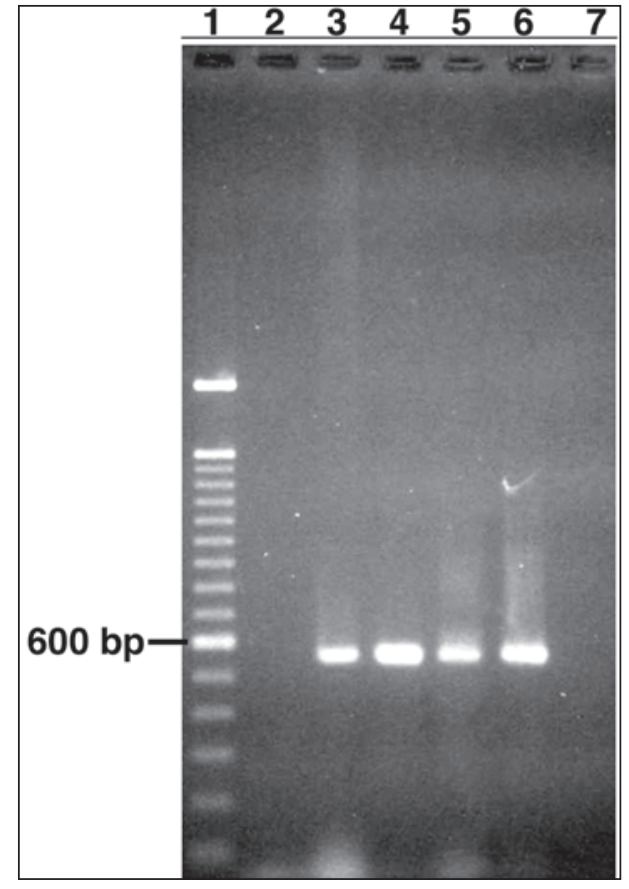

Figure 1. Agarose gel electrophoresis of a polymerase chain reaction (PCR) amplification, after 35 cycles, of the $16 S$ rDNA fragment from ash trees growing in Arizona. Lane $1=100 \mathrm{bp}$ molecular weight standard, lane $2=$ water control, lane 3 = native Fraxinus velutina, lane $4=$ Modesto ash from Tempe, lane $5=$ Modesto ash from outside Phoenix metropolitan area, lane 6 = Rio Grande ash, lane $7=$ F. uhdei .

Phoenix metropolitan area. Wild-type Fraxinus velutina and Rio Grande ash were observed with AD symptoms; the MSR values for these ash types indicate that the typical plant included within the survey was apparently healthy.

The results of the DAPI and PCR testing of the various ash entities (wild-type, Modesto, Rio Grande) growing in Arizona indicate some of these trees are infected with a phytoplasma pathogen, but a much lower percentage of individual trees were infected in comparison to the Modesto ash trees. A similar phytoplasma infects the native Arizona ash and the Modesto and Rio Grande cultivars, as evidenced by the same RFLP (restriction fragment length polymorphism) pattern obtained for each type of ash.

Based on the evidence (MSR values, and DAPI and PCR test results) presented in this paper, there are three possible explanations for the difference in symptom development in the Modesto ash cultivar and the other Fraxinus velutina types.

1. Modesto ash is a highly susceptible cultivar; the other types of ash growing in cultivation and the wild are less susceptible to AD than Modesto ash. 
2. The total number (according to the DAPI test results) of wild-type, Rio Grande, and evergreen ash trees that are infected by phytoplasmas is less than the total number of infected Modesto ash. Modesto ash would have a greater number of trees infected and displaying symptoms as well as higher MSR values than the other types of ash trees.

3. Infection of Modesto ash occurred prior to that in the other types of ash, the AD epidemic being at a more advanced stage than in the other types of ash found in Arizona.

The Modesto ash is most likely a cultivar highly susceptible to AD. This conclusion is supported by the observation that similar-aged Fraxinus velutina cv. 'Rio Grande' and F. uhdei trees can occur with Modesto ash trees in a landscape setting but do not exhibit advanced stages of AD.

Further study is required in order to more fully address why the Modesto ash currently has the highest rate of $\mathrm{AD}$ symptoms and phytoplasma infection among ash trees in Arizona. A long-term grafting transmissibility study using bark tissue from a single infected individual should be undertaken concurrently for all entities of ash currently found in Arizona. All trees should be completely enclosed during the study period to prevent possible transmission by a phytoplasma vector, and tissue samples should be taken at the beginning and end of the study for phytoplasma detection using DAPI and PCR.

Symptom development in ash trees infected with phytoplasma pathogens may be associated with water stress (Castello et al. 1985; Han et al. 1991). Growth decline in white ash trees infected with phytoplasmas and subjected to drought has been found to be more severe than with phytoplasma infection alone (Han et al. 1991). The Modesto ash may be less drought tolerant than the native Rio Grande or evergreen ash and thus exhibit higher mortality rates when infected by phytoplasmas.

It is clear at this juncture that the Modesto ash cultivar suffers a high mortality rate due to $\mathrm{AD}$. It is unclear, however, whether all ash species and cultivars growing in the southwestern United States will be as severely impacted by $\mathrm{AD}$ as the Modesto ash has been. Continued monitoring of Fraxinus spp. will ultimately determine which types of ash are effected by AD.

The results of our studies combined with Sinclair et al.'s (1990, 1994) observations in Utah indicate that the geographic distribution (Sinclair et al. 1990; Luley et al. 1992) of the ash decline type diseases should be expanded to include the southwestern United States. Currently, the only ash-decline phytoplasma host species verifiable by PCR is Fraxinus velutina. Fraxinus uhdei is not considered a host species in light of the negative PCR tests obtained from sample tissue, although seven of the 18 (38.8\%) F. uhdei trees tested using DAPI yielded a positive test, indicating possible phytoplasma infection. For the 18 trees tested using DAPI, nine were also tested by PCR, although none exhibited a $560 \mathrm{bp}$ fragment. In three of the nine cases in which trees were tested using both PCR and DAPI, a positive DAPI test was obtained. The samples subjected to the DAPI and PCR tests were collected at different times and locations in the canopy, and differences between the two tests may relate to the low titer and unequal distribution of the phytoplasma pathogen. Fraxinus anomala Torrey was previously tested for phytoplasma infection and is not believed to be affected (Sinclair et al. 1994).

\section{Effect of Sampling Strategy on Phytoplasma Detection in Host Tissue}

The DAPI staining test results indicate that detection of phytoplasmas is dependent on the type of host tissue sampled. Samples collected from symptomatic tissue yielded the highest percentage of positive DAPI tests followed by healthy tissues from the canopy, witches' broom shoot proliferation tissue, and roots, in that order. A variable concentration of phytoplasmas in ash host tissue has been documented (Sinclair et al. 1990) in white ash and in other hosts (Schneider 1977; Seemüller et al. 1984a, 1984b; Douglas 1986; Sheta 1988) using the DAPI test. Differences in phytoplasma distribution in host tissue have also been detected by Chen et al. (1989) and Kuske and Kirkpatrick (1992) utilizing DNA hybridization techniques.

Sinclair et al. $(1989,1992)$ suggested that white ash tissue sample collection for phytoplasma testing should be done from the small roots in different parts of the root system because tissue at the trunk base and in the root system had the highest phytoplasma titer in the plant. In the current study, $26.9 \%$ of root tissue samples compared to $71.1 \%$ of canopy tissue samples tested by DAPI tested positive for phytoplasmas. These results suggest that in Fraxinus velutina, root tissue is less reliable than canopy tissue for phytoplasma testing. Research by Kuske and Kirkpatrick (1992) on phytoplasma distributions in periwinkle supports this conclusion. That study found the highest phytoplasma concentration in actively growing regions; phytoplasma concentrations in roots was generally lower than in shoots. The sampling of root tissue would be recommended only during winter months, as more positive DAPI stain tests have been recorded in the root tissue of $F$. americana during the dormant season than during the growing season (Cha and Tattar 1991). It is believed that phytoplasmas reside in root tissue during periods of dormancy and then colonize host trunk and stem phloem tissue during the growing season (Douglas 1986).

The unequal distribution of phytoplasma particles should be taken into consideration when collecting tissue samples to diagnose AD. The results of both the DAPI and 
PCR methods indicate that tissue sampled from the tree canopy is most reliable for routine diagnostic work. In both tests, apparently healthy samples from the canopy yielded the highest percentage of positive tests. Testing of diseased tissue and of witches' broom shoot proliferations was superior to sampling from the root system.

\section{Comparison of DAPI and PCR Tests}

The DAPI staining technique was once a standard in phytoplasma detection and diagnosis (Douglas 1986; Chen et al. 1989; Sinclair et al. 1989, 1992). This test has been limited in its applications due primarily to low titers of phytoplasma particles. One of the polymerase chain reaction's most attractive features is its ability to detect DNA from organisms even when at extremely low concentrations. Our results indicate that using PCR for routine detection and diagnosis of phytoplasma infection is indeed superior to the DAPI stain test. This is especially true for asymptomatic individuals and in tissue where titers are low.

\section{CONCLUSIONS AND RECOMMENDATIONS}

Ash decline (AD) is a progressive disease of ash caused by a phytoplasma (Bricker and Stutz 2004). The causal agent of $\mathrm{AD}$, as documented in this paper, has been found to infect several different types of ash species and cultivars. Interestingly, susceptibility to AD varies according to host type. This information can be used when selecting material for the landscape setting. Modesto ash is not recommended for the urban landscape, while a resistant species such as Fraxinus uhdei would be a more appropriate choice, especially in the Phoenix and Tucson, Arizona, metropolitan areas.

Finally, the unequal distribution of phytoplasma particles should be taken into consideration when collecting tissue samples to diagnose $\mathrm{AD}$. The results of both the DAPI and PCR methods indicate that tissue sampled from the tree canopy is most reliable for routine diagnostic work. Apparently healthy samples from the canopy yielded the highest percentage of positive tests. Testing of diseased tissue and of witches' broom shoot proliferations was superior to sampling from the root system.

\section{LITERATURE CITED}

Ahrens, U., and E. Seemüller. 1992. Detection of DNA of plant pathogenic mycoplasmalike organisms by a polymerase chain reaction that amplifies a sequence of the 16S rRNA gene. Phytopathology 82:828-832.

Bricker, J.S., and J.C. Stutz. 1992. Etiology of Arizona ash decline (Abstr.). Phytopathology 82:1170.

_ 2004. Phytoplasmas associated with ash decline. J. Arboric. 30(3):193-199.

Castello, J.D., S.B. Silverborg, and P.D. Manion. 1985. Intensification of ash decline in New York State from 1962 through 1980. Plant Dis. 69:243-246.
Cha, B., and T.A. Tattar. 1991. Symptom development of ash yellows and fluctuation of mycoplasmalike organism population in white ash (Fraxinus americana L.). Arboric. J. 15:323-343.

Chen, T.A., D. Lei, and C.P. Lin. 1989. Detection and identification of plant and insect mollicutes, pp. 393424. In Whitcomb V. R.F. and J.G. Tully (Eds.). The Mycoplasmas. Academic Press, New York, NY.

Douglas, S.M. 1986. Detection of mycoplasmalike organisms in peach and chokecherry with X-disease by fluorescence microscopy. Phytopathology 76:784-787.

Han, Y., J.D. Castello, and D.J. Leopold. 1991. Ash yellows, drought, and decline in radial growth of white ash. Plant Dis. 75:18-23.

Kuske, C.R., and B.C. Kirkpatrick. 1992. Distribution and multiplication of western aster yellows mycoplasmalike organisms in Catharanthus roseus as determined by DNA hybridization analysis. Phytopathology 82:457-462.

Luley, C.J., M.E. Mielke, J.D. Castello, J. Cummings Carlson, J. Appleby, and R. Hatcher. 1992. Ash crown condition and the incidence of ash yellows and other insects and diseases in Illinois, Iowa, Missouri, and Wisconsin. Plant Dis. 76:1209-1212.

Schneider, H. 1977. Indicator hosts for pear decline: Symptomatology, histopathology, and distribution of mycoplasmalike organisms in leaf veins. Phytopathology 67:592-601.

Seemüller, E., L. Junze, and U. Schaper. 1984a. Colonization behavior of MLO and symptom expression of proliferation-diseased apple trees and declinediseased pear trees over a period of several years. Z. Pflanzenkrankh. Pflanzenshutz 91:525-532.

Seemüller, E., U. Schaper, and F. Zimbelmann. 1984b. Seasonal variation in the colonization patterns of mycoplasmalike organisms associated with apple proliferation and pear decline. Z. Pflanzenkrankh. Pflanzenshutz 91:371-382.

Sheta, M.H. 1988. Focus. Plant Dis. 72:4.

Silverborg, S.B., and E.W. Ross. 1968. Ash dieback development in New York state. Plant Dis. Rep. 52:105107.

Sinclair, W.A., Griffiths, H.M., and M. Treshow. 1994. Ash yellows in velvet ash in Zion National Park, Utah: High incidence but low impact. Plant Dis. 78:486-490.

Sinclair, W.A., H.M. Griffiths, R.E. Davis, and I.-M. Lee. 1992. Detection of ash yellows mycoplasmalike organisms in different tree organs and in chemically preserved specimens by a DNA probe vs. DAPI. Plant Dis. 76:154-158.

Sinclair, W.A., R.J. Luli, A.T. Dyer, and A.O. Larsen. 1989. Sampling and histological procedures for diagnosis of ash yellows. Plant Dis. 73:432435. 
Sinclair, W.A., R.J. Luli, A.T. Dyer, P.T. Marshall, J.A. Matteoni, C.R. Hibben, G.R. Stanosz, and B.S. Burns. 1990. Ash yellows: Geographic range and association with decline of white ash. Plant Dis. 74:604-607.

\author{
${ }^{1 *}$ Department of Biology \\ Nebraska Wesleyan University \\ 5000 St. Paul Avenue \\ Lincoln, NE 68504-2794, U.S. \\ jbricker@nebrwesleyan.edu.
}

${ }^{2}$ Department of Applied Biological Sciences

Arizona State University

Mesa, AZ 85212, U.S.

${ }^{*}$ Corresponding author.

Résumé. Le dépérissement du frêne est une maladie qui provoque une mortalité progressive causée par un phytoplasme et qui a été reportée par le passé sur le Fraxinus velutina. Les hôtes et la distribution de cette maladie sont décrits en se basant sur des échantillons recueillis à partir de frênes échantillonnés dans tout l'état de l'Arizona, et ce incluant à la fois des F velutina sauvages de milieux humides ainsi que des F velutina cv. Modesto, des F. velutina cv. Rio Grande et des F uhdei de milieux aménagés. Les résultats de cette enquête à l'échelle de l'état indiquent que le dépérissement du frêne se retrouve autant dans les frênes indigènes que dans les frênes ornementaux avec le F. velutina cv. Modesto qui montre le plus haut degré $(100 \%)$ de maladie dans la zone métropolitaine de Phoenix. Les individus sauvages de F. velutina et de F. velutina cv. Rio Grande montraient eux aussi des symptômes de cette maladie, mais à des fréquences et des degrés de sévérité plus faibles. F. uhdei ne montrait aucun symptôme de dépérissement du frêne. Linfection phytoplasmique a été détectée dans les trois types de F. velutina au moyen de deux tests différents, mais n’a pas été détectée chez le $F$. uhdei. Une fréquence plus élevée d’infection phytosplasmique a été détectée au sein des cimes par rapport aux racines, et ce en opposition avec des résultats antérieurs rapportés pour le frêne d'Amérique.
Zusammenfassung. Das Eschensterben ist eine progressive Krankheit, die kürzlich bei Fraxinus velutina berichtet wurde und von einem Phytoplasma verursacht wird. Die Wirtsspanne und die Verbreitung von Eschensterben wird hier diskutiert anhand von Proben, die an Eschen überall in Arizona, USA gesammelt wurden, einschließlich beider Wildtypen von F. velutina in unbesiedelten Gebieten, und F. velutina cv. Modesto, F. velutina cv. Rio Grande und F. uhdei in besiedelten Gebieten. Die Resultate dieser staatsweiten Untersuchung zeigten, dass Eschensterben in wilden und kultivierten Eschen gefunden wurde. F. velutina cv. Modesto zeigte den höchsten Krankheitsgrad (100\% ) im Stadtgebiet von Phoenix. Die Wildtype F. velutina und F. velutina cv. Rio Grande zeigte auch Krankheitssymptome, aber mit weniger Frequenz und Schwere. F. uhdei zeigte keine Symptome. Die Phytoplasma-Infektion wurde in allen drei Typen von F. velutina unter Verwendung von DAPI-Anfärbung und PCR entdeckt. Das galt nicht für F. uhdei. Höhere Häufigkeit von Phytoplasma-Infektionen wurde in der Krone versus zur Wurzel gefunden. Dies stand im Gegensatz zu früheren Untersuchen. PCR schien effizienter bei der Aufdeckung geringer Infektionslevel als die DAPI-Anfärbung.

Resumen. La declinación del Fresno (DF) es una enfermedad regresiva progresiva reportada previamente en Fraxinus velutina, que es causada por fitoplasma. El rango y distribución de DF es discutido con base en muestras colectadas de árboles de fresno muestreados a través del estado de Arizona, U.S.A., incluyendo tipos de áreas silvestres F. velutina en áreas riparias y F. velutina cv., Modesto, F. velutina cv., Rio Grande y Fraxinus uhdei en áreas urbanas. Los resultados del estudio indican que DF es encontrado en árboles nativos y cultivados con F. velutina cv. Modesto tiene el más alto (100\%) nivel de enfermedad en el área metropolitana de Phoenix, Arizona. F. velutina y F. velutina cv. Rio Grande exhibieron también síntomas de DF pero con más bajas frecuencias y severidad. F. uhdei no presentó síntomas de DF. La infección de fitoplasma fue detectada en todos los árboles de F. velutina, utilizando teñido DAPI y reacción de polímeros en cadena (PCR), pero no fue detectada en F. uhdei. Una frecuencia más alta de infección de fitoplasma fue detectada en la copa de los árboles versus raíces, en contraste con resultados previamente reportados en fresno blanco. PCR se encontró más eficiente para detectar el bajo nivel de infección típica de F. velutina en comparación con el teñido DAPI. 